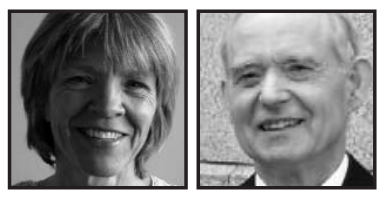

\title{
Teacher Explorations of Science and Science Learning Generate Insights Into Inquiry and Teaching
}

\author{
Fiona J. Hughes-McDonnell, Emmanuel College \\ David R. Burgess, Rivier College
}

\section{ABSTRACT}

Education and science faculty describe explorations introduced into a multi-year professional development program to promote teachers' abilities to create environments for the elementary and middle school students they teach which elicit learners' exploratory behavior and sustain them in authentic scientific inquiry. Experiences, which were informed by the teaching-learning research pedagogy of critical exploration (Duckworth, 2006a), involved teachers as co-collaborators and explorers of scientific phenomena and students' science learning. ${ }^{1}$

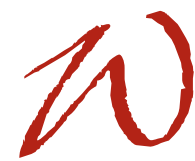

e are faculty members in the divisions of education and science at two small colleges in New England. For the last few years we have been collaborating on the design and development of a professional development program to support k-8 teachers in their efforts to teach science through inquiry. On this Saturday morning in late November we will meet with a group of sixteen k-8 teachers to explore students' science learning through sharing artifacts generated by their classroom teaching. In other sessions we engaged the teachers in exploring materials and phenomena that we presented to them. Involving teachers as explorers of scientific phenomena and students' science learning are two explorations which we have found generate the knowledge and insights needed to engender understanding of scientific concepts through engaging students in authentic scientific inquiry. This approach also reflects our deep trust in classroom teachers as 
decision-makers and diagnosticians of student learning, as well as our recognition of k-12 teachers as co-collaborators in researching teaching, learning and inquiry.

None of these teachers hold degrees in science. Upon entering this program, the majority self-identified as "science avoiders" and expressed a fear and uneasiness with teaching science, especially the idea of engaging students in inquiry as a means to support their understanding of scientific concepts. Moreover, no teachers in our program had any prior experiences with authentic scientific inquiry. All teachers reported using and relying upon district-mandated reading materials and science texts.

On this Saturday morning, to further our understanding of children's science learning, two teachers will share classroom videotape that shows two groups of second-grade students exploring an assortment of rocks and minerals that they selected to launch students into making their own explorations of rocks and minerals. The teachers have also brought a set of the students' science journals which contain drawings the students made, as well as the descriptions, questions and wonderings that occurred to them, as, through making close observations, they noticed and developed an increasing curiosity in the colors and textures exhibited by the various specimens. A teacher from a neighboring school district will share videotape excerpts that show the fifth-grade students she teaches using ideas they have put together about electrical circuits to construct a device of their choosing that contains a light bulb and a switch. In previous meetings, one teacher shared classroom videotape which documented the investigations that her fifth-grade students designed to understand the various factors that affect the motion of objects that they have launched. Another teacher shared videotape of the second grade students she teaches observing, describing, and drawing an assortment of leaves they have collected as part of a leaf study. She too shared journal entries the students made as part of their leaf explorations. One teacher team presented videotape that shows the fifthgrade students they teach making close observations of an assortment of flowers they had selected to stimulate thinking about structure, form, and function. One teacher team, motivated by contemporary events, shared videotape that showed the different investigations their students had planned and conducted to understand the biological and physical impacts of an oil spill on the environment. Another team shared videotape that showed two groups of second-grade students using materials they had gathered up from their homes (turkey syringes, hair dryers, tubing, sand, water, etcetera) to investigate questions they had about wind, wind speed and its effects on the environment. These teachers moved their teaching from the classroom into the gymnasium. In another session, a teacher who teaches science in the state's 
only alternative middle school, a school for "at risk" students, showed videotape of students observing, analyzing, and raising questions about soil samples collected from different locations around the city. Finally, a teacher new to the teaching profession from a long career in business, shared videotape of his seventh-grade students engaged in explorations which grew out of their observations of a burning candle flame. The idea resulted from his own reading of Michael Faraday's 1860 Christmas lectures for children (1993). As teachers prepare to depart this final Saturday meeting, two teacher teams announce that they have plans to extend their students' science experiences by initiating after-school science programming at their respective schools; one teacher team describes their plan to set up areas specifically designed to not only "nurture and prompt children's wonderings," but to also help children "pursue their wonderings." The teachers hope that their colleagues will notice these centers and become inspired to introduce exploratory learning into their classrooms. Two second grade teachers announce that they have plans to develop a series of workshops to give their colleagues experiences with learning science through exploration. One of these teachers, who upon enrollment in the program declared her fear of teaching science, reports that she has agreed to the request of her building supervisor to serve as a science mentor.

In this paper we describe two explorations that we introduced into a multiyear professional development program which the teachers report gave them insights into the nature of inquiry and students' science learning. Insights gained motivated teachers to create settings that suggest "wonderful ideas" (Duckworth, $2006 \mathrm{~b}$ ) to students, and to sustain students' autonomous learning by giving students opportunities to pursue ideas and questions they had about the various subject matters that engaged them. Teaching, learning and research became fused, approaching the pedagogy of critical exploration (Duckworth, 2006a), as the students of these teachers explored subject matter that their teachers presented to them, and teachers-assuming the role of teaching-researcher-explored the different ways that students were taking in and making sense of their new experiences.

\section{Context}

\section{Teaching Science Through Scientific Inquiry: A Call to Action}

It has been more than a decade since concern about students' lack of interest in science careers and their apparent lack of achievement in science, prompted the National Research Council [NRC] to put out the clarion call to make "inquiry into 
authentic questions generated by student experience the central strategy for teaching science" (National Research Council, 1996, p. 31). Yet, the call to make inquiry a central strategy for teaching science, and concern about students' lack of interest in science, is not unique to the United States. Education reform documents in Canada (see, for example, Foundation for the Atlantic Canada Science Curriculum, 1998) also put scientific inquiry, alongside the three traditionally recognized domains of science study (life science, physical science and earth-space science), as a fourth content area to be included in the k-12 science curriculum. The emphasis on inquiry-based teaching reflects the commitment of policy makers to promote student interest in science, and subsequent enrollment in science fields, as well as their knowledge of scientific concepts, by having k-12 students experience the science curriculum in a way that is reflective of and consistent with what scientists do and how students learn. The description of scientific inquiry presented below, while taken from US education reform documents, is consistent with descriptions of inquiry outlined in various documents available from the Canadian government:

Inquiry is a multifaceted activity that involves making observations; posing questions; examining books and other sources of information to see what is already known; planning investigations; reviewing what is known in light of experimental evidence; using tools to gather, analyze, and interpret data; proposing answers, explanations, and predictions; and communicating the results. (NRC, 1996, p. 23)

The call to implement scientific inquiry into the experiences of k-12 students has been taken up by the National Science Teachers Association [NSTA], which has chapters in Manitoba, Ontario, and Saskatchewan. A position statement released by this national organization urges teachers to make scientific inquiry "the centerpiece of the science classroom" (NSTA, 2004). Curriculum guidelines in the US and in Canada operationalize scientific inquiry as a set of discrete behaviors and skills, typically called science process skills.

Assessing scientific inquiry. In the United States, federal legislation (i.e., the No Child Left Behind Act of 2001) requires each state to conduct an annual assessment of k-12 student learning in mathematics and English language arts. Assessment of students' science learning, which is typically restricted to science content knowledge, is optional. A number of states choosing to conduct assessments in science have begun to introduce Science Performance Tasks as a mechanism to gather data on students' abilities to perform scientific inquiry. The nature of the science performance task varies by grade span. Tasks administered to students in early grades target 
students' abilities to make observations and generate questions. Students in the middle grades are required to plan and conduct small collaborative investigations using materials provided to them. Students in the secondary grade levels are required to interpret, analyze and evaluate data gathered through experiment.

\section{The Challenge of Implementing Scientific Inquiry}

Teaching science content through inquiry does not come without its challenges. Some teachers believe, as Bruce Robertson (2006) notes, that they have to make a choice between utilizing inquiry or teaching science content. Others may feel, as Marguerite Comley (2009) notes, that inquiry teaching compromises the science content learned. Comley notes that "questions and doubts may make it challenging for a teacher to feel confident implementing inquiry-based laboratories in their classroom" (p. 162). Developing the confidence to utilize inquiry to support students' science learning presents a challenge to all science teachers, including those who hold degrees in science. Comley cites research by Abd-El-Khalick et al. (2004) who assert:

Most science teachers have never directly experienced authentic scientific inquiry during their education in the sciences or within teacher education programs ... Teachers need to be well versed in scientific inquiry as a teaching approach, a set of process skills, and a content area. (Comley, 2009, p. 163)

Understanding scientific inquiry as a teaching approach presents a special challenge for teachers, who, like those in our program, do not have formal training in science and lack experiences learning science through inquiry. Providing this teacher population with experiences that promote their knowledge of scientific inquiry, as well as their appreciation for the central role of inquiry in supporting students' science learning is of critical importance. As early as 1991, Canadian researcher Ruth Fawcett warned:

The fact that teachers of the lower grades need have little specific science training brings a danger that many children will lose interest in the subject at a young age ... many of these [teachers] themselves have rejected science and may communicate their dislike and fear of the subject to their students. (Science Education section, para.4) 


\section{The Inquiry Learning Cycle: A Lesson Planning Model for Teachers}

The call for inquiry-based science teaching has provided a new market for publishers and curriculum developers. Across the country, k-12 teachers, teacher educators, and college science faculty are inundated with texts which utilize a lesson planning model referred to as the inquiry learning cycle. The model, developed by Myron Atkin and Robert Karplus (1962), draws on findings concerning the cognitive structure of children's learning reported by child psychologist Jean Piaget (18961980). The model is presented as having anywhere from three to six phases. The original model, as proposed by Karplus and Atkin, had three phases: discovery, invention and concept development. While this lesson-planning model can and does provide a useful framework for teachers in thinking about lesson design, curricula that follow solely from a model or template for lesson development rather than from observations, ideas and thoughts of the learner is sure to fall short, for students and their teachers. Something more is needed. What students need is to have access to teachers who follow and attend to their growth and development; what teachers need is to be acknowledged as researchers and diagnosticians of children's development and learning.

\section{Theoretical Framework}

As collaborating Education and Science faculty, our aim was to use our expertise to create experiences out of which the teachers might notice the environments, settings, and teaching behaviors which prove helpful to learners in pursuing their own learning. We sought to design a program which engaged teachers as classroom researchers of students' science learning such that they might gain the knowledge and insights they need to teach in ways that cohere with how students learn. Our challenge, we recognized, was to interact with these teachers in the same way that we hoped teachers would interact with the students they teach. We rejected using our authority to tell these teachers what they should know about scientific phenomena or how students learn. The challenge that we undertook was to use our individual expertise to collaborate on the design of situations which we hoped would allow the teachers to put these ideas together for themselves.

\section{Teaching, Learning and Research}

Eleanor Duckworth is a former student and translator of Jean Piaget (18961980). "Critical exploration in the classroom" (Duckworth, 2006a) extends into the 
classroom setting the clinical interview methodology that Jean Piaget and his colleague Bärbel Inhelder developed to research the origins and development of children's understanding within various domains. Duckworth reports that it was when she was field-testing curriculum materials with students in classrooms, seeking the different ways that students were taking in and making sense of the situations that she presented to them, that she noticed a possible inter-connection among teaching, learning and research. Duckworth noticed that her efforts to understand the thinking of the students proved useful to the students in taking their own ideas seriously. Exploration of student understanding became an act of teaching in the sense that it supported the students in coming to a deeper understanding of the materials and phenomena with which they were engaged (For Duckworth's own account see Duckworth, 2006b.) Teachers who utilize critical exploration in the classroom create situations in which children are "called upon to think, and to talk about what they think" (2006a, p. 159). It requires both student and teacher to become involved in exploration: “Exploration of the subject matter by the child (the subject or learner), and also exploration of the child's thinking by the adult (the researcher or the teacher)" (p. 159).

Teachers who create environments which are responsive to and supportive of the exploratory behavior of the learner are functioning as the kind of teacher scientist-philosopher David Hawkins (1913-2002) envisioned when he wrote,

The function of the teacher is to respond diagnostically and helpfully to a child's behavior, to make what he considers to be an appropriate response which the child needs to complete the process in which he's engaged in at a given moment. (1969/2002, p. 56)

The idea that a teacher's genuine interest in understanding the thoughts of learners (whether the learners be k-12 students or adults), as expressed through the teacher's active role in exploring the different ideas that learners have about the phenomena that engage them, proves useful to those same learners in taking their thoughts further, is a notion that informs our work with these teachers. (For examples of introducing critical exploration into the preparation of pre-service teachers, see Hughes-McDonnell, 2009; Cavicchi \& Hughes-McDonnell, 2001). 


\section{The Teacher Explorations}

\section{Teachers Explore Scientific Phenomena}

In one set of experiences we engage the teachers in active exploration of materials, phenomena and tasks that we present to them. We might, for example, present a carefully chosen assortment of materials (magnets of varying sizes and shapes or an assortment of spherical objects of different sizes and masses along with ramps of different lengths and materials) and challenge the teachers to see what they can discover about the materials and/or phenomenon in question. Oftentimes, we present teachers with a question, prediction, or challenge that we hope is sufficiently rich to take them inside the subject matter such that they might encounter the structure and complexity of that subject matter. In addition to exploring what the teachers are thinking at the outset of an exploration, we typically ask the teachers to consider how the students they teach might apprehend (Schneier, 2001) and respond to the particular situation presented. We ask the teachers to consider the full range of responses that students might give and to find or "give reason" for each prediction (Duckworth, 2006c, p. 83). We find that this approach helps to alleviate teacher anxiety, while deepening teachers' appreciation for the student perspective and providing a context for exploring different ways of thinking about and explaining events. We continue this approach throughout the teachers' explorations. We invite the teachers to share their initial observations and wonderings so that these observations, questions, and wonderings might become the basis of subsequent explorations. Teachers share their new explorations with the group and reflect together on their learning and understanding.

\section{Teachers Explore Students' Science Learning}

In a concurrent set of explorations we involve the teachers in exploring the science learning of the students they and their colleagues are teaching. We encourage the teachers to use their own experiences as science learners to create exploratory settings for the students they teach. We emphasize the active basis of learning research, and communicate that, as teaching-researchers, their actions should parallel the exploratory behavior they hope to observe in students. We encourage the teachers to be genuinely curious about what students are thinking and doing: to create situations and pose questions which open up and uncover student thinking; to make note of what students say and do, to gather up the student work products generated by their teaching (student journals, posters, drawings, models, etcetera), and to document with videotape episodes of teaching and learning as it is happening. It is these artifacts which we examine at the Saturday sessions to 
further our individual and collective understanding of the indicators of inquiry and of actions that support and sustain inquiry. That is, teachers do not share artifacts as exemplars of teaching and learning but as contexts through which to further our understanding of how students learn and teaching behaviors that support students in pursuing their own inquiries. It is essential that we maintain an individual and collective stance of inquiry. To this end we have adopted and subsequently modified an inquiry-based looking at student work protocol developed by Steve Seidel at Project Zero, Harvard University (Blythe, Allen, \& Powell, 1999).

\section{Overview of the Professional Development Program}

The experiences that we describe in this paper are taken from our third and final year of a multi-year professional development program, which has been made possible by funding received through the federal Mathematics-Science Partnership program. Each year of programming built on previous experiences. In 2006, we engaged 25 teachers in open inquiry experiences using as a context science content identified in state curriculum frameworks. We engaged teachers in conducting and developing Science Performance Tasks. The following fall and spring the teachers met for two hours each month to share student work products that were generated by small inquiry experiences that they were providing for their students. For the most part, the inquiry experiences that teachers were providing for students were taken from mandated curriculum materials issued to them by the school district. The following year (at the request of one district administrator) we included a mentoring component. We adopted a mentoring model that supported ideas that we had been developing about inquiry teaching (Zubrowski, Troen, \& Pasquale, 2007). We subsequently replaced the terms mentor and mentee with the concept of collaborating partners. The teachers visited the classroom of their collaborating partner for the specific purpose of gathering data related to questions about teaching and learning that were of interest to the host teacher. Teachers presented their teacher research projects at the spring 2009 meeting of New Hampshire Science Teachers Association. In this, our third and final year of working with this group of teachers, the teachers met for five days in the summer of 2010 to design and produce inquiry-based curriculum units which enact ideas and insights gained through their involvement in explorations associated with the program. It is artifacts generated by the enactment of these curricula that the teachers gather and share at the Saturday meetings. 
Involving classroom teachers as co-collaborators in conducting research into students' science learning is a form of professional development that is supported by leadership within the National Science Teachers Association. A position statement released by the NSTA board in September 2010, reads: "the Association 'encourages ALL participants in science education, including k-12 teachers of science ... to assume active roles in research practices'"' [caps in original].

\section{The Teachers}

The teachers in the current group are drawn from 10 elementary and middle schools across six public school districts in New Hampshire. Seven of the 16 teachers in the current and final group have participated since the project's inception in summer 2008; five teachers joined the program in the fall of 2008; we accepted an additional two teachers in the summer of the final year of the program. Seven reported three or less years of teaching experience upon entering the project. Six teachers reported between four and six years of classroom experience. Two teachers reported between seven and 10 years classroom experience. One person in the group reported more than 20 years teaching experience. At the time of their participation, nine of the 16 teachers were teaching in grades four and five; five participants were teaching in the second grade; and two participants were assigned to the eighth grade. The group consisted of 13 women and three men.

Teacher attrition. Five of the 16 teachers in the current group have participated in all phases of the programming we have developed. A number of teachers joined the group in Years Two and Three of the programming while others have been lost. A mentor teacher component introduced in Year Two of the project resulted in substantial teacher loss. Further attrition resulted when, as result of sensitivity to district needs, we moved from a weekday to a Saturday meeting schedule.

\section{Teacher Reflections}

In this section, we present some of what the teachers have shared with us and with project evaluators about the nature of their experiences and insights gained. The reports speak to teachers' growing trust in themselves as curriculummakers, decision-makers, and diagnosticians of learning, as well as their respect for students as explorers and sense-makers. The reports illuminate teachers' deepening appreciation for the exploratory roots of authentic teaching and learning, and the 
power of real-world subject matter to elicit exploratory behavior. The reports reveal teachers' insights into practices that sustain exploratory behavior, such as observing, noticing, and documenting the diverse ways that students apprehend and interact with subject matters presented, and listening attentively to how students describe and explain those actions. Most importantly, the reports illuminate teachers' new appreciation for students' observations, questions, and wonderings as "material to work with." Finally, the accounts indicate the potential of documentation and collaboration to produce individual and systemic change.

The teacher accounts are taken from a number of sources, including teacher surveys, written reflections (both formal and informal), field notes that we made during the professional development sessions, and transcriptions of the teacher meetings that we videotaped in the fall of 2010. Unless otherwise noted, teacher comments are taken from a Saturday morning session held November 20, 2010.

\section{"I was a ten-year-old scientist"}

Several teachers noted the value of exploring scientific phenomena in what they now appreciate as important elements in engaging learners in scientific inquiry. One teacher with less than five years teaching experience reported, "[My] experience designing ramps and 'playing' with things that rolled moved my understanding from science inquiry being just 'hands-on' to exploring and developing further questions to investigate..." [Underline in original] (Anonymous, program evaluation, November 2010).

A teacher with three years experience commented, "I wasn't a teacher in training ...I was a ten year old scientist, thinking about my own experiences in a garden, looking at the moon on the horizon, and realizing that crickets eat cornmeal" (Cummings, 2010).

A fourth-grade teacher with three years teaching experience reported,

I like how we learned and discovered through our own experience. This is how we should be teaching our students-through experience.... I now find myself thinking about the questions, my own and the students'... I allow my students time to develop their own questions about the subject matter and give them time and opportunity to find the answer to their own questions. (Anonymous, program evaluation, November 2010) 
A second-grade teacher with five years teaching experience, reported,

I used to be anxious and not comfortable with science and the inquiry process. My content knowledge and comfort has grown year after year. I'm [now] more comfortable with teaching science. I'm excited about and enjoy teaching science. I've increased my science content knowledge. I now have more ideas about what to say and what to do to support students in making their own inquiries. I am more comfortable learning what kinds of questions to ask. (Anonymous, program evaluation, November 2010)

\section{"I have become a student of learning"}

The teachers expressed awareness that exploring and documenting students' science learning was especially useful in helping them to create settings which are effective in promoting children's exploratory behavior. As one teacher, Rebecca Cummings, put it, "I feel like I have taken a journey with Piaget." This research and the understandings generated, transitioned teachers from classroom teacher to teacherleader. A fifth-grade teacher with nine years teaching experience wrote,

"I have gone from giving the answer to following the learning I see happening in front of me. I have become a student of learning" (Anonymous, program evaluation, November 2010).

A middle school teacher with eight years teaching experience commented,

My greatest personal growth has occurred from observing how students learn, through reflections, observations and videotaping, students and myself in action. My ability to ask questions to probe student learning has greatly improved. The ability to observe children actually interacting in the learning process gave a concrete presence to our notions about how learning takes place. (Underline in original)

Another teacher stated that researching students' learning has helped her to "Put the focus on the child ... it helps me to see how a particular child is reaching their understanding" (Anonymous, program evaluation, November 2010). Moreover, through documenting students' science inquiries, this group of teachers began to notice teaching behaviors that are essential for involving and supporting children in making their own authentic scientific inquiries. Another teacher reported, "Last week at a parent-teacher conference I could tell a mother, 'he had a brilliant question 
the other day,' and I could remember the process he went through to get there" (Anonymous, program evaluation, November 2010).

\section{Learners' Ideas as "material to work with" and "songs to build on"}

If limited to one insight that the teachers happened upon, which we believe proved essential to their new understanding of what it means to teach, we would argue for teachers' new awareness, appreciation, and respect for the role and value of children's ideas for teaching. Today, these teachers seek out students' ideas, questions and wonderings with the same energy and drive that they seek out new materials for the supply table. No longer do these teachers perceive children's questions and ideas as thoughts to be avoided, corrected, or covered up. Today these teachers value the ideas and questions that learners bring as "material to work with" and "songs" (Cummings, 2010) to build on. At our last fall meeting, one teacher exclaimed,

I used to be so afraid of what my students would say. I never, never would have given up control; I would have wanted to tell them what to think. Now I think, let's let them go there. I wonder, now, how far will they take this? I look forward to seeing what material they will give me that I can work with.

One teacher, in an anonymous program evaluation, shared the revolution that has taken place in the way she thinks about teaching.

There's been a sort of revolution in my teaching. . . Now, students make observations first, come up with questions, and then try to dive into the answers on their own. I am there to guide, not to tell. Afterwards, we discuss what we all noticed and the students take their own notes. There is a new sense of pride within the classroom.

Another teacher also used the program evaluation to report,

... this project has given me the tools to not only have more fun while teaching science, but to teach it in a meaningful way that involves the children in observation, exploration and experimentation. The children are more involved and responsible for their learning as the subject and discussion is directed by them, their interests and their questions. 


\section{To "hear their voices in their work"}

Teachers have transitioned from perceiving teaching as telling and providing answers to seeing teaching as involving listening to the ideas and explanations that students have about events (Duckworth, 2001). One teacher reported that her new capacity for listening to what each student is trying to express, through looking closely at the things they produce and the words they use in conveying their ideas, has brought her closer to her students and helped her to know them as individuals beyond the label "student." Fifth-grade teacher Rebecca Cummings (2010) wrote,

Just as these students have learned to develop their skills through patient observations I feel that I have developed my ability to listen without trying to manipulate their ideas to fit an objective. . Fostering their experiences instead of capitalizing on their learning has now become my goal. Reading their written words and watching as they draw what they see allows me to hear their voices in their work.... I can pinpoint their [my students'] understanding. I can draw on it. I actually see their learning. (p. 5)

\section{"I was ... king of the castle... I have given up the throne"}

Teachers' genuine curiosity, what Freire (1970/2006) might refer to as "epistemological curiosity," in knowing and understanding what their students are seeing, thinking and wondering for the purpose of supporting their developing ideas has had a dramatic impact on the nature of the questions they pose to students and in how they think about the purpose of the activities that they plan for their students. An eighth-grade science teacher, who entered teaching from a career in business, reflected

I [used to think] that science teaching was to be done out of a book-or out of a kit, step by step. I was the point of knowledge-'king of the castle'-I have [now] given up the throne and now have shifted that power to the kids. They are responsible for their learning. I am a guide... I used to worry about the clarity of the explanations that I gave to students. Now I do a lot more listening to my students. I find myself genuinely interested in hearing what my kids have to say.

\section{"Initially I was skeptical": Having Confidence in Student's Wonderings and Questions}

Of some significance is that these teachers trust that students' explorations 
will uncover the science content that they are required to teach. A second grade teacher with five years teaching experience reported, "Initially I was skeptical that kids could and would have questions that would lead to uncovering the content that I was responsible to cover. I'm confident now that they can and will become more invested learners."

Making inquiries into scientific phenomena and following students' science learning has deepened teachers' appreciation for the social origins and context of individual and group learning. The teachers now recognize group discussion, in which learners are called upon to share their diverse observations and ideas about situations experienced, whether the observations concern the motion of an object along a plane or the thinking of a student, as a valued activity and an intellectual necessity to their own learning. In a written reflection, fifth-grade teacher, Rebecca Cummings (2010) wrote,

All I had to do was prompt them with materials, questions, give them a venue for their ideas to be valued. Most importantly, I had to listen.... As their teacher I should always be listening and my own talk is limited to helping them decipher their own thoughts, develop their questions, and give meaning to their vocabulary. (p. 5)

\section{"I can be the facilitator [of learning] and present the material in a real way."}

Teachers who began the project fearful of science have now assumed leadership positions within their district and many have begun to provide students with additional exploratory science experiences through initiating after-school science programming. Teachers' facility for teaching science through inquiry is paralleled by their students' increased interest in science. One fourth-grade teacher reported that before her participation in the program, her students "were bored reading the textbook and answering assessment questions." Since her participation in the program, she has "noticed a difference in students' attitudes [toward] science. They cheer when we transition into science, and if science isn't in our schedule for the day, they ask if we can fit it in somewhere before going home." Whereas these teachers used to adhere to a scripted curriculum, they now create their own curriculum in response to the ideas and interests that their students express. One teacher shared how, in one recent experience, she searched her home for "junk" materials that her students might use to build devices to explore wind and its effects, taking her students into the gymnasium where they would have more space for their explorations. "This is 
something I can't imagine myself ever having the courage to do this before [my involvement with this project]." A second-grade teacher reported that before her involvement with the project, "I really never taught any science. The material I have is dated and uninteresting. This project took the intimidation factor away and I have realized that I can be the facilitator and present the material in a real way."

\section{Challenges}

In the schools where our participants teach there continues to be a strong focus and emphasis on literacy and mathematics, which does not leave much time for science instruction of any kind. In many cases students are expected to learn science through reading stories or articles that have a reference to science, or that are about science; and reading about science rather than doing science, continues to be considered as valid science instruction. Some of the schools, mostly those in larger districts, have implemented scripted curricula in which every aspect of teaching is written out for the teachers. In science they may purchase a curriculum using kits where the students do some hands-on activities, but it is still scripted; questions and inquiries are provided to students and there is little opportunity for students to experience phenomena and to design investigations around questions they have. Some of our teachers have experienced resistance from colleagues who are not willing to change what they are doing and so trying to introduce inquiry to them is very difficult. Some participants have experienced indifference from administrators who ascribe to the view of inquiry articulated in purchased curriculum. Yet, despite these challenges, the teachers in our program are forging ahead with their work, doing what they can do to introduce the students they teach to authentic inquiry, and thereby improve their students' science learning, as well as their images of and experiences with science.

\section{Closing Comment}

As this project comes to a close, not only are the teachers who participated in our program making time to teach science, but they are also teaching science through inquiry. A number of teachers are taking ideas they have gained about the nature of learning into their teaching of other subjects. And, despite some resistance, these teachers are seeking out opportunities and avenues to introduce inquiry to their colleagues. We feel the enormous trust and confidence that these teachers have in themselves and in each other, both as teachers, learners and researchers. These teachers document student learning with the understanding that the artifacts that 
they gather and share are vital to furthering the knowledge base on teaching and learning. As one teacher said, "We know that the group is not there to judge us but to help us record our kids' learning. Judging and evaluation has gone by the wayside." We notice the confidence with which these teachers point to the actions, thoughts, gestures, etcetera, which they consider to be either evidence of learning or teaching actions supportive of exploration. The teachers are eager to see what others will bring to the table and listen with curiosity and attentiveness as teachers share their thoughts and observations about the artifact in question. These teachers appreciate that knowledge and understanding of teaching comes from making extended inquiries into student learning.

Finally, Hamos et al. (2009) highlight the use of professional learning communities (PLCs) in supporting teacher learning. Professional learning communities, they write,

...open the classroom door wide so that teachers can discover ways to improve their craft through group effort, discuss with others ways to improve the education of all students, and generally create a culture of mutual support within school walls. (p. 23)

We did not set out with the idea to form a PLC, yet, the development of community is a natural outcome of this work. It is our shared commitment to exploring the nature of development and learning which brings us together on this Saturday morning.

\section{Notes}

1. This research was supported in part by grants from the New Hampshire Department of Education and U.S. Department of Education from the Mathematics Science Partnership program NH080107, NH080104, NH080101. 


\section{References}

Abd-El-Khalick F., BouJaoude, S., Duschl, R., Lederman, N., Mamlok-Naaman, R., Hofstein, A., et al. (2004). Inquiry in science education: International perspectives. Science Education, 88, 397-419.

Atkin, J. M., \& Karplus, R. (1962). Discovery or invention? Science Teacher 29(5): 45.

Blythe, T., Allen, P., \& Powell, B. (1999). Two ways of looking at student work. In Looking at student work (pp. 26-37). New York: Teachers College Press.

Cavicchi, E., \& Hughes-McDonnell, F. (2001). Introducing inquiry into the experiences of new teachers of science. Proceedings of the Annual Meeting of the History of Science Society, Denver: CO. Retrieved November 14, 2010 from http://www.eric.ed.gov/ PDFS/ED470928.pdf.

Comley, M. (2009). The inquiry-based science pedagogy debate. LEARNing Landscapes 2(2), 153-164. Retrieved November 10, 2010, from http://www.learnquebec.ca/ export/sites/learn/en/content/learning landscapes/documents/LL-no4-spring 2009.pdf.

Cummings, R. (2010). My revised teaching style: Why I listen to my students. Unpublished manuscript, Rivier College, $\mathrm{NH}$.

Duckworth, E. (2001). "Tell me more": Listening to learners explain. New York: Teachers College Press.

Duckworth, E. (2006a). Critical exploration in the classroom. In E. Duckworth, "The having of wonderful ideas" and other essays on teaching and learning (3rd ed.) (pp. 157-172). New York: Teachers College Press (Original essay published in 2005, The New Educator, 1, 257-272).

Duckworth, E. (2006b). The having of wonderful ideas. In E. Duckworth, "The having of wonderful ideas" and other essays on teaching and learning (3rd ed.) (pp. 1-14). New York: Teachers College Press.

Duckworth, E. (2006c). Understanding children's understanding. In E. Duckworth, "The having of wonderful ideas" and other essays on teaching and learning (3rd ed.) (pp. 83-97). New York: Teachers College Press.
Duckworth, E. (2010). The soul purpose. LEARNing Landscapes, 3(2), 21-28. Retrieved November 14, 2010, from http://www. learnquebec.ca/export/sites/learn/en/con tent/learninglandscapes/documents/LLno6-june2010-low-res.pdf.

Faraday, M. (1993). The chemical history of a candle. Marietta, GA: Cherokee Publishing. (Original work published in 1861).

Fawcett, R. (1991). Science education in Canada. Depository Service Program, Government of Canada. Retrieved March 23, 2011, from http://dsp-psd.pwgsc.gc.ca/CollectionR/LoPBdP/BP/bp265-e.htm.

Foundation for the Atlantic Canada Science Curriculum (1998). Science: Foundations. Retrieved March 23, 2011, from http://www.ednet.ns.ca/pdfdocs/curricu lum/camet/foundations-science.pdf.

Freire, P. (2006). Pedagogy of the oppressed. New York: Continuum International Publishing Group (original work published in 1970).

Hamos, J. E., Bergin, K.B., Maki, D.P., Perez, L.C., Prival, J.T., Rainey, D.Y., et al. (2009). Opening the classroom door: Professional learning communities in the Math and Science Partnership Program. Science Education, 18(2), 14-24.

Hawkins, D. (2002). I, Thou and It. In D. Hawkins (Ed.), The informed vision: Essays on learning and human nature (2nd ed., pp. 51-64). New York: Algora Publishing. (Original essay published in 1969).

Hughes-McDonnell, F. (2009)."I wonder how this little seed can have so much potential?" Critical exploration supports pre-service teachers' development as science researchers and teachers. The New Educator 5(3), 205-228. Retrieved October 10, 2010, from http://www1.ccny.cuny.edu/ prospective/education/theneweduca tor/volume5_3.cfm.

National Research Council (1996). National science education standards. Washington, DC: National Academy Press.

National Science Teachers Association (2004). NSTA Position Statement: Scientific inquiry. Arlington, VA: NSTA Board of Directors. 
Retrieved December 3, 2010, from http://www.nsta.org/about/positions/res earch.aspx.

National Science Teachers Association (2010). NSTA Position Statement: The role of research on science teaching and learning. Arlington, VA: NSTA Board of Directors. Retrieved November 22, 2010, from http://www.nsta.org/about/positions/res earch.aspx.
Robertson, B. (2006). Getting past "inquiry versus content." Educational Leadership (2006-07 Dec-Jan).

Schneier, L. (2001). Apprehending poetry. In E. Duckworth (Ed.) "Tell me more:" Listening to learners explain (pp. 42-78). New York: Teachers College Press.

Zubrowski, B., Troen, V., \& Pasquale, M. (2007). Making science mentors: a 10 session guide for middle grades. Arlington, VA: NSTA Press.

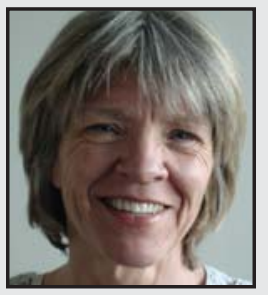

Fiona Hughes-McDonnell is associate professor of science education at Emmanuel College, Boston, where she is also the director for the Center for Science Education. A former high school science teacher, she has partnered with her colleague David Burgess for five years on developing in-service opportunities for teachers. She completed her doctoral degree at Harvard University in the field of Teaching, Curriculum, and Learning Environments where she studied under Eleanor Duckworth and from whom she learned the methodology of critical exploration.

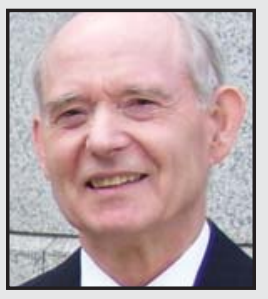

David Burgess is a professor at Rivier College in Nashua, New Hampshire. He received his Ph.D. from lowa State University in Physical Chemistry and has been teaching chemistry, physics and physical science for 30 years. In addition he has collaborated with several faculty in the education department at Rivier College, doing online and face-to-face professional development, writing and editing a series of Discovery Books, and most recently investigating teaching and learning in elementary and middle school classrooms. 